\title{
Upper extremity prosthesis 3D bio-pneumatic self-adjusting clamping to non- homogeneous surfaces under the principle of communicating vessel
}

\section{Prótesis de extremidad superior 3D bio-neumática de sujeción autoajustable a superficies no homogéneas bajo el principio de vasos comunicantes}

\author{
PERALTA-MEZA, Angel†**, DURÁN-NÚÑEZ, Félix Arnoldo and PENDONES-FERNÁNDEZ, José \\ Angel
}

Instituto Tecnológico Superior de Nuevo Casas Grandes

ID 1 ${ }^{\text {st }}$ Author: Angel, Peralta-Meza / ORC ID: 0000-0003-0295-3545

ID $1^{\text {st }}$ Co-author: Félix Arnoldo, Durán-Núñez / ORC ID: 0000-0001-998-8781, CVU CONACYT ID: 1010275

ID $2^{\text {nd }}$ Co-author: José Angel, Pendones-Fernández / ORC ID: 0000-0001-6993-1995, CVU CONACYT ID: 660600

DOI: 10.35429/JBEB.2021.13.5.1.7

Received March 10, 2021; Accepted June 30, 2021

\begin{abstract}
There are several models that emulate the mechanical behavior of biological tissues. Its automation, new materials and manufacturing techniques will enable its use in the near future. This research is based on the use of compressed air in pneumatic muscles that actuate the phalanges. The research is important because it proposes a system that adapts to the needs and economic accessibility or people with limited resources. The problem to solve is that it meets certain standards such as: stable grip and pressure and that it adapts to irregularly shaped objects with more natural movements. The principle of communicating vessels and the force exerted by a fluid on the walls of the container that is used. Consequently, the fluid exerts pressure in all directions. The prosthesis with the design of the Flexy Hand 2 is manufactured by inserting pneumatic muscles to each of the fingers connecting them by means of nylon ropes that are attached to the homemade pneumatic muscles connected to a common manifold, regulating the pressure by means of a valve and a degree of freedom. As a result of the above, it can be concluded that the prototype worked favorably.
\end{abstract}

Prosthesis, Muscle, Pneumatics

\begin{abstract}
Resumen
Existen varios modelos que emulan el comportamiento mecánico de los tejidos biológicos. Su automatización, nuevos materiales y técnicas de fabricación, posibilitará su uso en un futuro cercano. El motivo de esta investigación se basa en aire comprimido utilizando músculos neumáticos que accionen las falanges. La Importancia de la investigación es un sistema que se adapte a las necesidades, accesibilidad económica de personas con escasos recursos. El Problema para resolver es que cumpla con ciertas cualidades como: sujeción y presión estable y que se adapte a objetos de forma irregular de movimientos más naturales. Se utiliza el principio de vasos comunicantes y de la fuerza que ejerce un fluido sobre las paredes del recipiente que lo contiene. Por consiguiente, el fluido ejerce presión en todas direcciones. Se fabrica la prótesis con diseño de la Flexy Hand 2 insertándole músculos neumáticos a cada uno de los dedos conectándolos mediante cuerdas de nylon que están sujetas a los músculos neumáticos de fabricación casera conectado a un múltiple en común, regulando la presión por medio de una válvula y un grado de libertad. A raíz de lo expuesto se puede concluir que el prototipo funcionó favorablemente.
\end{abstract}

Prótesis, Músculo, Neumática

Citation: PERALTA-MEZA, Angel, DURÁN-NÚÑEZ, Félix Arnoldo and PENDONES-FERNÁNDEZ, José Angel. Upper extremity prosthesis 3D bio-pneumatic self-adjusting clamping to non-homogeneous surfaces under the principle of communicating vessel. Journal of Biomedical Engineering and Biotechnology. 2021. 5-13: 1-7

\footnotetext{
* Author Correspondence (e-mail: angel27p@hotmail.com)

$\uparrow$ Researcher contributing as first author.
} 


\section{Introduction}

In this work, a support system for the prosthesis is proposed under the principle of communicating vessels. That is, with this system the prosthesis can hold any amorphous object, just by activating a pneumatic solenoid valve (one degree of freedom) and regulating the pressure, to increase its holding force. The proposal arises from the need to develop a simpler biomechanical prosthesis, with less reaction time and more economical, since the cost increases in proportion to the applied technology and increasingly complex algorithms for each desired movement. Until its construction and design are unified or standardized, you will not be able to increase its performance and decrease its cost. It is required to cover this need for hand prostheses and for them to perform daily functions.

Motor learning is a process of acquiring skills to perform actions with dexterity, which results from experience and practice and which produces permanent changes in behavior (A Schmidt \& Timothy Donald Lee, 2011), It has also been established that the early start of training and the practice of specific tasks favor motor learning (Shumway Cook \& $\mathrm{H}$. Woollacott, 2016), Some studies have shown that increasing training intensity could lead to better results (B.H, 2005) (Kwakkel, 2002), Some robotic devices are used to assist sensorymotor stimulation, obtaining significant improvements in motor recovery of retrained muscles (Chu Kazerooni, 2005).

An essential component of robotic assistance devices is the user interface, which communicates the machine with man, allowing interaction between them and the monitoring of signals from the equipment and the patient during use.

Additionally, interactive computer programs have been used with sensory feedback (biofeedback) which is provided to the patient through acoustic and visual signals and it is possible to analyze and monitor some motor functions (Chevallereau, 2003). Slow muscle contractions represent a challenge in the design of myoelectric prostheses, due to their low levels of activation and the difficulty in their differentiation with different signal patterns.
The interest in this type of contraction is based on the fact that the prosthesis will be able to perform finer movements and with little intensity of force (Villarejo Alcalde, Bastos, Godinez, \& Frisera, 2015). However, Peerdeman also indicates other important deficiencies that are: appearance, comfort and above all functionality, these are the main causes of the rejection of prostheses by users and the results indicate that there is a need to include a greater number of functions, less reaction times and execution and intuition of the control and feedback systems (Peerdeman, 2011).

It is understood that pneumatic muscles cannot be adopted in industrial applications where high repeatability, high positioning precision, high speed and high durability are necessary(Gabrio Antonelli, Beomonte Zobel, D'Ambrogio, \& Durante, An Analytical Formula For De Mckibben Pneumatic Muscles, 2018). Studies show that daily life tasks of great relevance to amputees are, among others, making the bed, grasping objects, and the use of cutlery (Sensinger, 2009).

Some existing prostheses provide individual finger control. Others select different grips discreetly. In all of them the individual control of the fingers is close to natural, but it is more complex and less intuitive (Villarejo Mayor, Mamede Costa, Frizera-Neto, \& Freire Bastos, 2017). In summary, many works have used sEMG signals (Romo, Realpe, \& Jojoa, 2007), to be able to accurately identify different hand positions. By which it is understood that a more intuitive system is required to facilitate gripping and holding tasks.

The trend according to (Páez Chingal \& Gaviria López, mayo 2017), is to manufacture adaptive prostheses in their grip, with greater autonomy and feedback in real time that classifies according to anthropomorphism, functionality in dexterity and controllability. In the latter, a greater number of sensors and more real kinematic structures of the fingers have been incorporated, but this has brought more complex controls. Although Diaz, J. C., indicates that pneumatic prostheses powered by compressed carbonic acid, provides a large amount of energy. The disadvantages of these devices are the complicated parts and accessories, and the risk in the use of carbonic acid, its use was interrupted due to the technical difficulties presented (Diaz, 2009). 
However, Jair L. Loaiza indicates that the trend of using complex and bio-inspired, flexible and personalized mechatronic systems, together with advanced manufacturing processes and new materials, will allow to overcome the weaknesses and disadvantages present in current prostheses, which are robust, reliable and economically viable (Arzola \& Loaiza, 2011).

On the other hand, the Degree of Freedom (DOF) is defined as the necessary and sufficient number of variables that uniquely define the position and orientation of all the links in the kinematic chain. (López Cajún \& Ceccarelli, 2008), this means that having many degrees of freedom allows them to perform manipulations with dexterity, but they require complex energy transmission devices, numerous sensors for their control, and make the operation of the device by the patient very complex, in addition to its cost becomes quite high (Clement, Ella Bugler, \& Oliver, Diciembre de 2011).

So, from the above it is understood that the difficulty of adapting to multiple tasks is directly proportional to the number of degrees of freedom to control a prosthesis, easy training, quick learning. Therefore, the objective is to design and build a prototype with a minimum of DOF to perform the grip, resorting to the principle of communicating vessels of the pneumatic muscles to improve grip adaptability, with visual feedback and that fulfills the function of adapting to different inhomogeneous objects. A system with pneumatic muscles is proposed, the prosthesis built in $3 \mathrm{D}$ printing with the design of the Flexi Hand 2 (Rodríguez \& Saldaña, junio 2018), with a degree of freedom, and to be able to verify if it is feasible in terms of: acquisition price, support to execute essential functions, simulation of more natural movements, less reaction time.

\section{Materials and methods}

\section{D print}

For the construction of the prosthesis, PLA and TPU filament is used, the latter as a flexible element (Ancajima Rodríguez, 2019), For this purpose, a 3D printer Model P802NR2 Ver 1.0 was used. Figure No 1 shows said printer, with a CAD-CAM Repetier-Host V2.0.0 operating software.

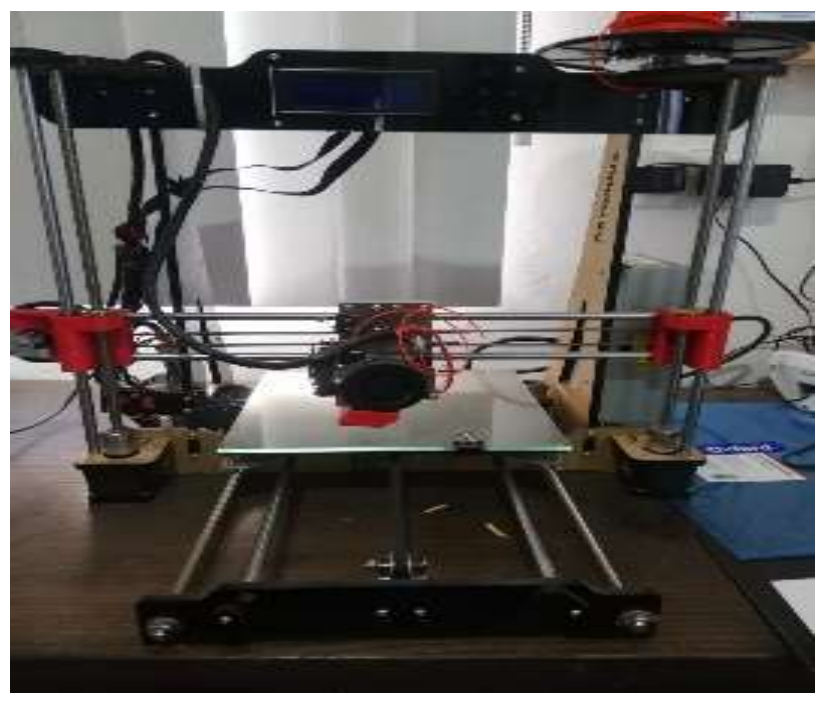

Figure 1 3D Printer Model P802NR2

Source: Printer's own photo

The software indicates how much material is used for construction in each of the prosthesis pieces figure 2 .

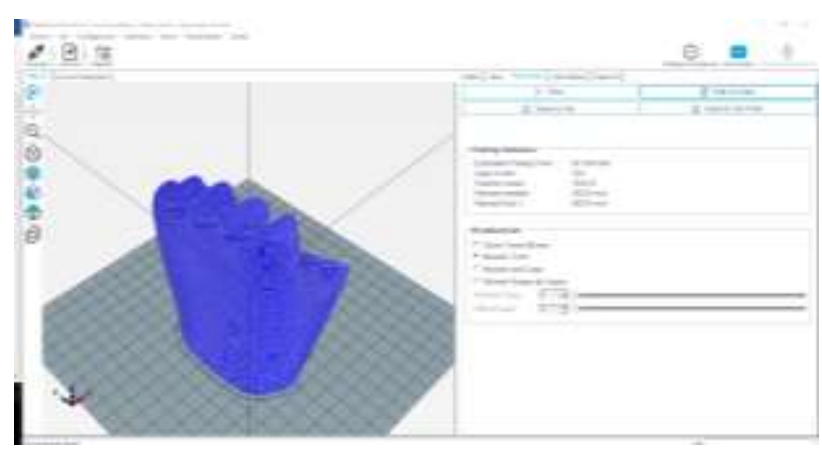

Figure 2 Repetier-Host V2.0.0 with 3D model Source: screen print

To assemble the muscle at the end of the sleeves, the pivot figure 3 is inserted, of an expandable sleeve of $3 / 4$ of an inch with an initial diameter of $20 \mathrm{~mm}$ and a maximum diameter of $25 \mathrm{~mm}$ with a roll with 10 meters at a cost of $\$$ 336 pesos, 5 are used $15 \mathrm{~cm}$ pieces, Figure 4

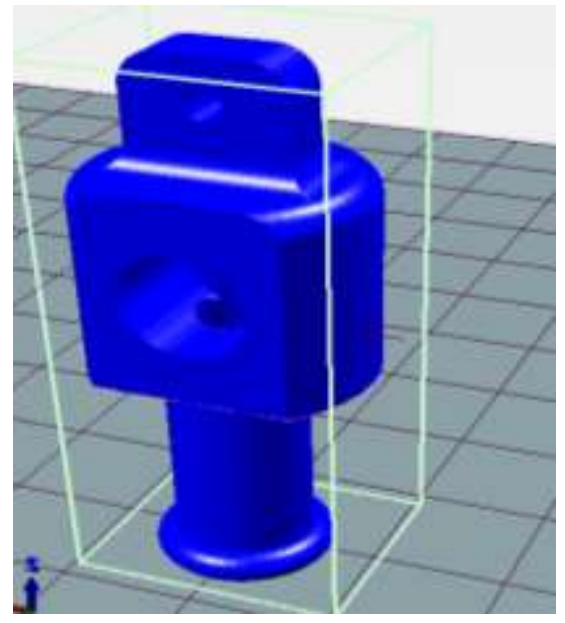

Figure 3 Design pivot

Source: Own Design Solid Works

PERALTA-MEZA, Angel, DURÁN-NÚÑEZ, Félix Arnoldo and PENDONES-FERNÁNDEZ, José Angel. Upper extremity prosthesis 3D bio-pneumatic self-adjusting clamping to non-homogeneous surfaces under the principle of communicating vessel. Journal of Biomedical Engineering and Biotechnology. 2021 


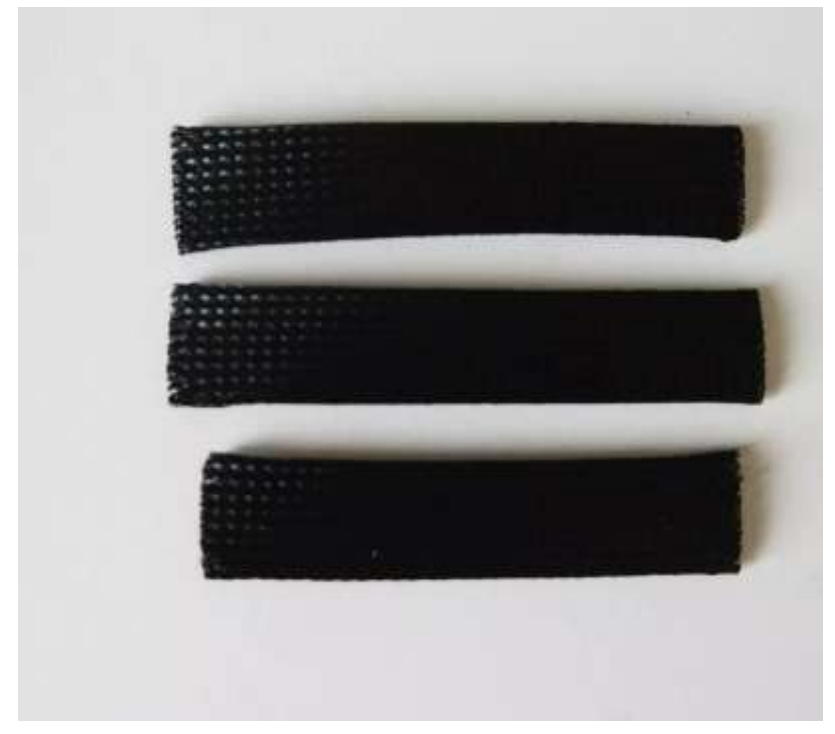

Figure $415 \mathrm{~cm}$ expandable sleeve

Source: Google photos

In the internal part of the sleeve the five are inserted, one for each sleeve representing one for each phalanx, the balloons with a price of 1 peso each figure 5 .

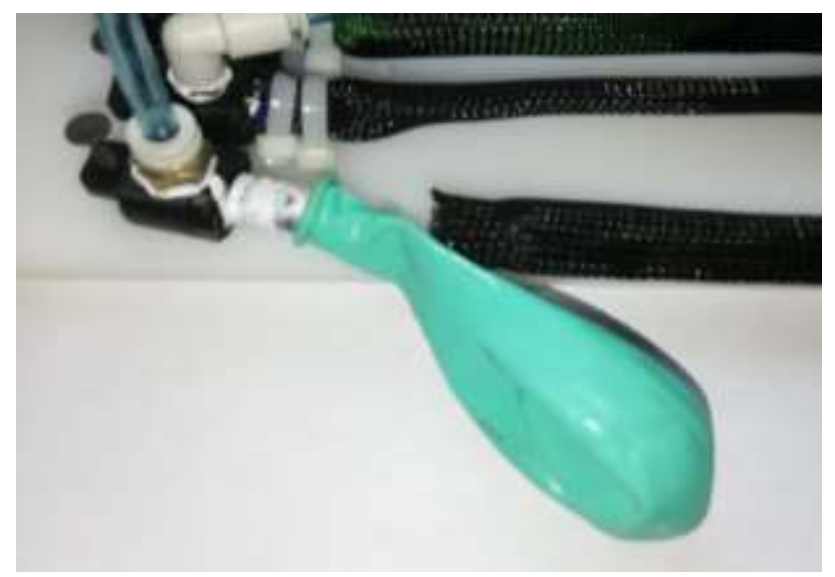

Figure 5 Balloons

Source: Own Design

\section{Fluid pressure}

Hydrostatic pressure causes in fluids at rest, a "force" perpendicular to the walls of the container or to the surface of the object, regardless of the orientation of the faces. Therefore, applying this principle and the set of vessels (muscles) communicated inferior superior or lateral that receives the name of communicating vessels, it can be deduced; that the force exerted by the muscles will be the same.(E. Tippens, 2001) A diagram is shown in figure 6 of pneumatic connections that consists of a $3 / 2$ valve with mechanical actuation.

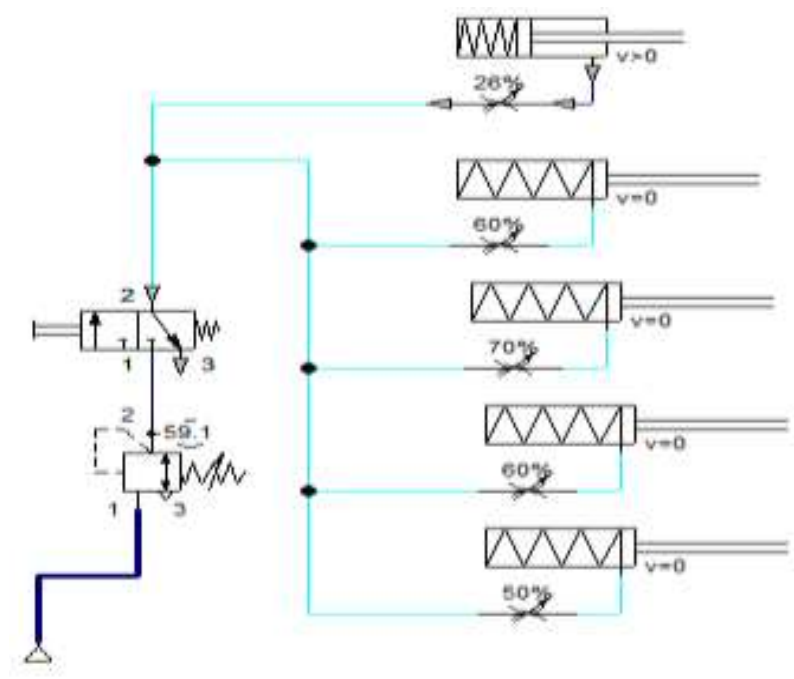

Figure 6 Pneumatic diagram Source: Own elaboration in fluidsim software

Teleoperated pneumatic 3D prosthesis with a servo valve with a unique pneumatic control system, using the Flexi hand 2 and pneumatic muscles with a closed pressure system. The internal communication between the communicating vessels allows the pressure to be the same in any direction, that is to say that, although each finger of the prosthesis is independent, it is not so for the whole system, since it is only a servo valve against pressure.

\section{Results}

The finished prototype can be seen in Figure 7, the muscles, prosthesis and drive system can be seen.

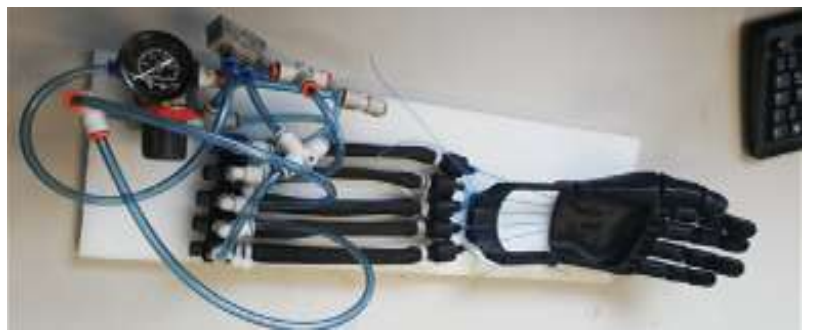

Figure 7 Prosthesis with pneumatic drive Source: (Meza, 2019)

According to the objectives of this project such as: a) acquisition price b) support to perform essential functions c) simulation of more natural movements d) reaction time. 
a) Precio de adquisición

\begin{tabular}{|c|c|c|c|}
\hline length & Description & $\begin{array}{l}\text { Weight in } \\
\text { grams }\end{array}$ & $\begin{array}{c}\text { Price } \\
\$ 400 / \mathrm{kg}\end{array}$ \\
\hline $25.215 \mathrm{~m}$ & Hand body PLA & 75.26 & $\$ 30.104$ \\
\hline 17.064 & Finger PLA & 50.26 & $\$ 20.104$ \\
\hline 3.4 & $\begin{array}{l}\text { Finger- hinge wrist } \\
\text { TPU }\end{array}$ & 10.1 & $\$ 4.04$ \\
\hline 8.092 & $\begin{array}{l}\text { Gauntlet long } \\
\text { winder wrist PLA }\end{array}$ & 24.14 & $\$ 9.65$ \\
\hline \multirow[t]{2}{*}{$1.914 * 10$} & $\begin{array}{l}\text { Tendon attachment } \\
\text { pibote }\end{array}$ & 57.0 & 22.7 \\
\hline & Total & $216.7 \mathrm{~g}$ & $\$ 86.84$ \\
\hline
\end{tabular}

Table 1 Elements made with PLA and $1.75 \mathrm{~mm}$ TPU Source: self made

\section{b) Restraint to perform essential functions}

To test the hypothesis that the prosthesis has an inhomogeneous grip, a Chi Square test was carried out with a significance level of 5\% (.05), in which the following was defined:

H0: There is no difference between the proportions of the different types of grip.

H1: There is a difference between the proportions of the different types of grip.

The observed frequencies of occurrence were recorded. Table 2 shows the results of the statistical analysis and a goodness of fit test was performed with the Chi Square statistic and yielded the following results.

\section{Goodness-of-fit test}

\begin{tabular}{|c|c|c|c|c|c|c|}
\hline \multicolumn{3}{|c|}{ Category } & Fo & $\begin{array}{c}\text { Test } \\
\text { Proportion }\end{array}$ & fe & $\begin{array}{l}\text { Contrib } \\
\text { To Chi- } \\
\text { Sq }\end{array}$ \\
\hline \multicolumn{3}{|c|}{ Agarre de pinza } & 2 & 0.142857 & 3.14286 & 0.14558 \\
\hline \multicolumn{3}{|c|}{ Agarre lateral } & 1 & 0.142857 & 3.14286 & 1.46104 \\
\hline \multicolumn{3}{|c|}{ Agarre de gancho } & 5 & 0.142857 & 3.14286 & 1.09740 \\
\hline \multicolumn{3}{|c|}{ Agarre esférico } & 5 & 0.142857 & 3.14286 & 1.09740 \\
\hline \multicolumn{3}{|c|}{ Agarre cilíndrico } & 5 & 0.142857 & 3.14286 & 1.09740 \\
\hline \multicolumn{3}{|c|}{ Agarre de precisión } & 0 & 0.142857 & 3.14286 & 3.14286 \\
\hline \multicolumn{3}{|c|}{ Agarre amorfo } & 4 & 0.142857 & 3.14286 & 0.23377 \\
\hline $\mathrm{N}$ & $\mathrm{DF}$ & Chi-Sq & \multicolumn{2}{|c|}{ P-Value } & & \\
\hline 22 & 6 & 8.54545 & \multicolumn{2}{|c|}{0.201} & & \\
\hline
\end{tabular}

Table 2 Chi Square test

Source: self made

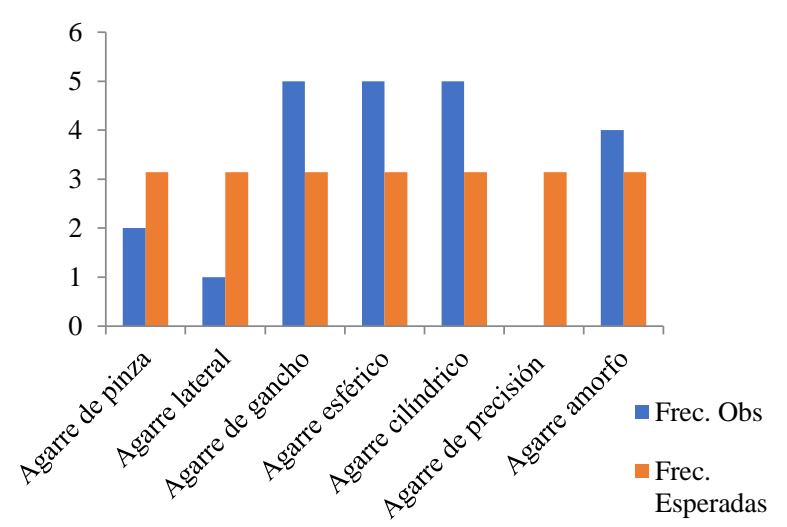

Graph 1 Observed vs Expected Frequencies Source: self made

\section{c) Reaction time}

Qualitatively, it can be observed that the reaction time compared to the aforementioned robotic systems is almost instantaneous (No Hysteresis).

\section{d) Natural movements}

In the same way, evaluating qualitatively and observing their movements, they are not robotic or robotic, on the contrary, their movements are quite subtle.

\section{Acknowledgments}

We are grateful to the Higher Technological Institute of Casas Grandes and the National Technological Institute of Mexico for the support provided to carry out this research.

\section{Conclusions}

It follows that the price per construction of this prosthesis is economically viable, taking into account that $3 \mathrm{D}$ printing systems are becoming cheaper in terms of design and construction and acquisition of materials, they can be found very easily, this means that better prosthesis are becoming more accessible for personalized designs.

Minitab analysis of observed versus expected frequencies of clamping and grip types, with a "p-value" higher than 0.05 , show that the null hypothesis is not rejected, and it can be concluded that "There is no difference between the proportion of the different types of grip", which statistically confirms that the prosthesis has an inhomogeneous and uniform grip. 
Reaction time and less robotized movements, are acceptable, this system contains only one degree of freedom and is easy to program and control.

Another of the particular qualities compared to prosthetic systems powered with servomotors, is that it does not have to be programmed for each desired movement and that it is limited to holding only certain objects and increasing the list of algorithms for each action and training by the user.

An advantage of the system is that it does not consume electrical energy, it would only be used in subsequent investigations for control elements and not for power.

Regarding the requirements of greater force in the pneumatic prosthesis, it is observed that a servo valve is required to regulate the pressure, to control the force and grip of objects of greater weight, whose variable is not included in this investigation.

\section{References}

A Schmidt, R., \& Timothy Donald Lee. (2011). Control motor y aprendizaje: un énfasis conductual. Champaign, IL, EE. UU: Human Kinetics.

Ancajima Rodríguez, J. P. (2019). Selección de material de fabricación para prótesis utilitaria de extremidad superior impresa en 3D. Piura: PIRHUA.

Arzola, N., \& Loaiza, J. L. (2011). EVOLUCIÓN Y TENDENCIAS EN EL DESARROLLO DE PRÓTESIS DE MANO. Dyna, pp. 191-200.

B.H, D. (2005). "Rehabilitation and functional neuroimaging dose-response trajectories for clinical trials.". Neurorehabilitation and neural repair, Vol 19 No. 4, pp 276-282.

Chevallereau, B. A.-d.-w. (2003). "RABBIT: A Testbed for Advanced Control Theory". IEEE Control Systems Mag, Vol. 23 No. 5, pp. 57-79.

Chu Kazerooni, H. Z. (2005). "On the Biomimetic Design of the Berkley Lower Extremity Exoskeleton (BLEEX)". Proceedings of the IEEE, No. April, pp. 4345-4352.
Clement, R., Ella Bugler, K., \& Oliver, C. (Diciembre de 2011). Manos protésicas biónicas: una revisión de la tecnología actual y las aspiraciones futuras. Revista del Real Colegio de Cirujanos de Edimburgo, 336-400.

Darwin, G., Caldwell,, A., Razak and M, \& Goodwin . (1993). BRAIDED PNEUMATIC MUSCLE ACTUATORS. Dept. of Electronic Eng - University of Salford. Manchuter, 522527.

Diaz, J. C. (2009). Mecanismos de transmision y actuadores utilizados en protesis de mano. Memorias del congreso XV anual se la SOMIM UNAM, Mexico D.F, pp. 335-343.

E. Tippens, P. (2001). Física, Conceptos y aplicaciones. México, D.F: Mc Graw Hill.

Festo. (2019). Festo. Retrieved from https://www.festo.com/group/es/cms/10233.ht $\mathrm{m}$

Gabrio Antonelli, M., Beomonte Zobel, P., D'Ambrogio, W., \& Durante , F. (2018). An Analytical Formula For De Mckibben Pneumatic Muscles. International Journal of Mechanical Engineering andTechnology, Volume 9, PP 320-337.

Gabrio Antonelli, M., Beomonte Zobel, P., D'Ambrogio, W., \& Durante, F. (12 de December de 2018). An Analytical formula for designing McKibben pneumatic muscles. International Journal of Mechanical Engineering and Technology, 320-337.

Gavrilovic, M., \& Maric, M. (1969). Positional Servo- Mechanism Activated by Artificial. Printend in Great Britain, 77-82.

Giraldo Rozo, A. M., \& Cifuentes Lozano, C. A. (2018). Análisis de búsqueda de recursos financieros para beneficiar a niños de bajos recursos con prótesis $3 d$ de miembros superiores. Bogotá D.C: Uniempresarial Negocios Internacionales.

Kwakkel, G. a. (2002). "Effect of duration of upper- and lower-extremity rehabilitation sessions and walking speed on recovery of interlimb coordination in hemiplegic gait.". Physical therapy, Vol. 82 No. 5, pp. 432-448. 
López Cajún, C. S., \& Ceccarelli, M. (2008). Mecanismos: Fundamentos cinemáticos para el diseño y optimización de maquinaria. México: trillas.

Meza, A. P. (2019, 08 13). Prótesis de extremidad superior 3D bio neumática de sujeción autoajustable a superficies no homogéne. Retrieved from https://www.youtube.com/watch?v=8mkNYpI ULuw

Owen, J., Owen, I., Liam, Schull, J., Simon, J., \& Esquela, M. (2019, agosto 13). Habilitando el futuro. Retrieved from Una red global de voluntarioe apacionados que utilizan la impresion 3D para dar al mundo una "mano amiga": http://enablingthefuture.org/upperlimb-prosthetics/the-flexy-hand/

Páez Chingal, I. G., \& Gaviria López, C. A. (mayo 2017). Prótesis subactuadas de manos humanas: una revisión. Ingenium, pp. 20-34.

Peerdeman, B. B. (2011). Myoelectric forearm prostheses: state of the art from a user-centered perspective. The Journal of Rehabilitation Research and Development, 48(6), 719. DOI: 10.1682/JRRD.2010.08.0161.

Rodríguez, V. A., \& Saldaña, J. J. (junio 2018). Prótesis en impresiones 3D de bajo costo "Hand to Hand". III Congreso internacional de Clencia y Tecnologia para el desarrollo Sostenible, 5255.

Romo, H. A., Realpe, J. C., \& Jojoa, P. E. (2007). Análisis de Señales EMG Superficiales y su Aplicación en Control de Prótesis de Mano. Medellín: redalyc.org.

Schulte, Jr, H., Adamski, D., \& Pearson, J. (1961). Characteristics of the Braided Fluid Actuator. Washington, D. C.: The University of Michigan.

Sensinger, J. L. (2009). Adaptive pattern recognition of myoelectric signals: exploration of conceptual framework and practical algorithms. IEEE Transactions on Neural Systems and Rehabilitation Engineering, 17(3), 270-278. DOI: 10.1109/TNSRE.2009.2023282. Shadow. (2019). Retrieved from Robot Company:

https://www.shadowrobot.com/products/dexter ous-hand/
Shumway Cook, A., \& H. Woollacott, M. (2016). Motor Control:Translating Research Into Clinical Practice. Philadephia, Pennsylvania: Wolters Kluwer.

Villarejo Alcalde, J. J., Bastos, T., Godinez, R., \& Frisera, A. (2015). Reconocimiento de Tareas para una Prótesis Mioeléctrica Basado en Wavelet. Academia.

Villarejo Mayor, J., Mamede Costa, R., FrizeraNeto, A., \& Freire Bastos, T. (2017). Decodificación de Movimientos Individuales de los Dedos y Agarre a Partir de Señales Mioeléctricas de Baja Densidad. Revista Iberoamericana de Automática e Informática Industrial, 184-192. 